\title{
Isolation and Characterization of Endophytic Bacteria from Tembelekan (Lantana camara L.) as Antibacterial Compounds Producer
}

(Isolasi dan Karakterisasi Bakteri Endofit dari Tanaman Tembelekan (Lantana camara L.) sebagai Penghasil Senyawa Antibakteri)

Dina Dyah Saputri ${ }^{1 *}$, Maria Bintang ${ }^{1}$, Fachriyan H. Pasaribu ${ }^{2}$

${ }^{1}$ Department of Biochemistry, Bogor Agricultural University, Bogor, 16680, Indonesia ${ }^{2}$ Department of Animal Infectious Disease and Veterinary Public Health, Bogor Agricultural University, Bogor, 16680, Indonesia

*Corresponding author: Dina Dyah Saputri; Departemen Biokimia, Jl. Agatis Gd. Fapet Lt. 5, Wing 5, Bogor 16680; Telp/Fax.+62856 4224 8992; E-mail: dinadyahsaputri@yahoo.com

\section{ABSTRACT}

Endophytic bacteria are microorganisms that live in the internal tissues of plants and have symbiotic mutualism with their host plants. Endophytic bacteria may produce secondary metabolites that can be developed for medical, agricultural, and industrial purposes. Lantana camara is a medicinal plant that has therapeutic potential to treat a variety of diseases such as fever, tuberculosis, rheumatism, asthma, and skin disease. The purpose of this study was to isolate and characterize endophytic bacteria from Lantana camara which has potential to produce antibacterial compounds. The method of this research include isolation of endophytic bacteria of Lantana camara. Antibacterial activity assay was done against four types of pathogenic bacteria i.e. Bacillus cereus, Escherichia coli, Staphylococcus aureus, and Salmonella enteritidis. Characterization of endophytic bacteria was by $16 S$ rRNA gene analysis and identification of antibacterial compounds by GC-MS analysis. Isolation of endophytic bacteria from Lantana camara resulted in BT22 as a potential isolate. Analysis of $16 \mathrm{~S}$ rRNA gene showed that the BT22 isolate was similar to Bacillus amyloliquefaciens YB-1402 with $99 \%$ identity. The results of GC-MS analysis showed some antibacterial compounds such as: Cyclohexanone, 2-[2-(1,3-dithiolan-2-yl)propyl]-6-methyl-3-(1-methylethyl), Octadecane (CAS) nOctadecane and Tetracosane (CAS) n-Tetracosane.

Keywords: antibacterial compounds, endophytic bacteria, Lantana camara L., $16 S$ rRNA 


\section{ABSTRAK}

Bakteri endofit merupakan mikroorganisme yang hidup di dalam jaringan internal tumbuhan dan bersimbiosis mutualisme dengan tumbuhan inangnya. Bakteri endofit dapat memproduksi senyawa metabolit sekunder yang dapat dikembangkan dalam bidang medis, pertanian, dan industri. Tembelekan (Lantana camara) merupakan tanaman obat yang memiliki potensi terapeutik yang dapat mengobati berbagai penyakit seperti demam, TBC, rematik, asma, dan penyakit kulit. Tujuan dari penelitian ini adalah untuk mengisolasi dan mengkarakterisasi bakteri endofit dari tanaman Tembelekan yang berpotensi sebagai penghasil senyawa antibakteri. Metode yang digunakan dengan mengisolasi bakteri endofit dari tanaman Tembelekan. Uji aktivitas antibakteri dilakukan terhadap empat jenis bakteri patogen yaitu Bacillus cereus, Escherichia coli, Staphylococcus aureus, dan Salmonella enteritidis. Karakterisasi bakteri endofit dilakukan dengan analisis gen 16S rRNA dan identifikasi kandungan senyawa antibakteri dengan GC-MS. Isolasi menghasilkan isolat potensial BT22. Analisis gen 16 S rRNA menunjukkan bahwa isolat BT22 memiliki kemiripan sebanyak 99\% dengan Bacillus amyloliquefaciens YB-1402. Hasil analisis GC-MS menunjukkan beberapa senyawa antibakteri di antaranya: Cyclohexanone, 2-[2-(1,3-dithiolan-2-yl)propyl]-6-methyl-3-(1-methylethyl), Octadecane (CAS) n-Octadecane dan Tetracosane (CAS) n-Tetracosane.

Kata kunci: antibakteri, bakteri endofit, Tembelekan (Lantana camara L.), 16S rRNA

\section{PENDAHULUAN}

Tanaman Tembelekan (Lantana camara L.) merupakan tanaman liar yang memiliki potensi terapeutik karena adanya senyawa bioaktif flavon, isoflavon, flavonoid, antosianidin, lignan, katesin, isokatesin, alkaloid, tanin, saponin dan terpenoid (Deepak et al. 2009). Ekstrak tanaman Tembelekan (Lantana camara L.) dapat digunakan untuk mengobati berbagai jenis penyakit seperti demam, TBC, rematik, asma, dan penyakit kulit (Dalimartha 2007). Ekstrak dari bunga, daun, batang, dan akar Lantana camara L. menunjukkan aktivitas antibakteri terhadap Escherichia coli, Pseudomonas aeruginosa, Staphylococcus aureus, dan Staphylococcus saprohiticus (Mary 2011).

Bakteri endofit merupakan mikroorganisme yang hidup di dalam jaringan internal tumbuhan dan bersimbiosis mutualisme dengan tumbuhan inangnya tanpa menyebabkan gejalagejala penyakit (Bhore \& Satisha 2010). Kajian mengenai manfaat mikroba endofit telah banyak dilakukan. Penapisan bakteri endofit dari tanaman binahong dan ketepeng cina menghasilkan senyawa antibakteri patogen, yaitu Escherichia coli DH5a, Pseudomonas aeruginosa, Staphylococcus aureus, Bacillus cereus, dan Enterobacter sakazaki (Purwanto 2013).

Tanaman Tembelekan memiliki banyak manfaat terutama di bidang medis. Kajian mengenai pemanfaatan senyawa aktif dari bakteri endofit asal tanaman Tembelekan sejauh ini belum dilaporkan. Bakteri endofit yang berada dalam tanaman Tembelekan diduga mampu menghasilkan senyawa aktif yang memiliki aktivitas yang sama dengan tanaman inangnya. Berdasarkan hal tersebut, tujuan dari penelitian ini adalah untuk mengisolasi dan mengkarakte- 
risasi bakteri endofit dari tanaman Tembelekan (Lantana camara L.) dengan analisis gen 16S rRNA serta menganalisis senyawa antibakteri yang dihasilkan oleh isolat potensial bakteri endofit dengan GC-MS.

\section{METODOLOGI}

Tanaman Tembelekan (Lantana camara L.) diperoleh dari area kampus Institut Pertanian Bogor, Darmaga, Bogor, Jawa Barat. Isolat bakteri patogen Bacillus cereus, Escherichia coli, Staphylococcus aureus, dan Salmonella enteritidis berasal dari koleksi Laboratorium Bakteriologi Bagian Mikrobiologi Medik Fakultas Kedokteran Hewan, Institut Pertanian Bogor, Darmaga, Bogor, Jawa Barat. Media pertumbuhan bakteri yang digunakan dalam penelitian ini adalah media Nutrient Agar (NA) produk Oxoid dan media Nutrient Broth (NB) produk Difco.

\section{Isolasi Bakteri Endofit (Modifikasi Desriani et al. 2013)}

Sampel berupa serabut akar (S), batang (B), dan daun (D) tanaman tembelekan (Lantana camara L.). Sampel dicuci lalu direndam etanol 96\% selama 1 menit. Setelah itu, cairan perendam dibuang dan diganti dengan sodium hipoklorit 5.25\% lalu didiamkan selama 5 menit. Cairan perendam dibuang kembali dan dibilas dengan etanol 96\% sebanyak tiga kali. Sampel yang telah steril dipotong lagi menjadi beberapa bagian lalu ditanam pada media Nutrient Agar (NA) yang telah ditambahkan nistatin $(200 \mu \mathrm{L} /$ $200 \mathrm{~mL}$ ) dan diinkubasi pada ruang gelap dan dilakukan pengamatan setiap hari hingga terdapat koloni yang tumbuh. Pemurnian dilakukan dengan memindahkan koloni yang tumbuh pada media NA yang ditambahkan nistatin ke cawan
Petri yang berisi NA steril. Setelah diperoleh biakan murni, bakteri endofit disimpan ke agar miring NA.

\section{Uji Aktivitas Antibakteri (Simarmata et al. 2007)}

Uji aktivitas antibakteri dari isolat bakteri endofit terhadap patogen dilakukan dengan menggunakan metode inokulasi titik. Isolat bakteri endofit dari agar miring diregenerasi ke media NA, sedangkan bakteri uji diregenerasikan ke dalam $5 \mathrm{~mL}$ media Nutrient Broth (NB) lalu diinkubasi selama 24 jam pada suhu $28-30{ }^{\circ} \mathrm{C}$. Sebanyak $0.4 \mathrm{~mL}$ kultur cair bakteri uji dimasukkan ke dalam $80 \mathrm{~mL}$ media NA yang bersuhu $\pm 40^{\circ} \mathrm{C}$. Selanjutnya $20 \mathrm{~mL}$ dituangkan ke dalam cawan Petri steril dan ditunggu hingga memadat. Isolat bakteri endofit yang akan diuji diinokulasikan ke media berisi patogen, lalu diinkubasi selama 24-48 jam. Zona hambat yang terbentuk diamati dan diukur. Isolat bakteri endofit yang positif menunjukkan zona hambat terhadap semua patogen dikatakan sebagai isolat potensial.

\section{Analisis Sekuen Gen 16S rRNA(Kusumawati} 2014)

Analisis sekuen gen 16S rRNA meliputi preparasi DNA cetakan dari isolat potensial, amplifikasi DNA dan penentuan urutan basa DNA, dan analisis hasil sequencing dengan BLAST. Preparasi DNA dilakukan dengan sentrifugasi koloni isolat potensial yang telah disuspensikan ke dalam larutan garam steril. Pelet diresuspensi dengan penambahan $0.5 \mathrm{~mL}$ InstaGene Matrix (Bio-Rad, USA). Setelah itu, diinkubasi pada suhu $56^{\circ} \mathrm{C}$ selama 30 menit, lalu dipanaskan $100^{\circ} \mathrm{C}$ selama 10 menit. Kemudian supernatan yang berisi DNA cetakan siap digunakan untuk 
proses amplifikasi. Amplifikasi DNA dilakukan 35 siklus dengan kondisi denaturasi awal $94^{\circ} \mathrm{C}$ selama 45 detik, annealing (penempelan primer) $55^{\circ} \mathrm{C}$ selama 60 detik dan elongasi (pemanjangan) pada suhu $72^{\circ} \mathrm{C}$ selama 60 detik. Purifikasi produk PCR dengan Montage PCR Clean up kit (Milipore). Setelah itu, ditentukan urutan basa DNA (sequencing) dari hasil PCR dengan menggunakan dua primer (518F dan 800R) dan Big Dye terminator cycle sequencing kit (Apllied BioSystem, USA), lalu dianalisis menggunakan Applied Biosystem model 3730XL automated DNA sequencing system (Apllied BioSystem, USA). Analisis hasil sequencing berupa urutan basa DNA menggunakan BLAST guna mengidentifikasi jenis bakteri endofit tersebut.

Pembuatan pohon filogenetik (Singh et al. 2011)

Pohon filogenetik digunakan untuk mengetahui hubungan kekerabatan isolat potensial dengan spesies lain. Pembuatan pohon filogenetik dilakukan dengan menggunakan software ClustalX2 dan dilanjutkan dengan NJPlot.

\section{Fermentasi dan Ekstraksi Senyawa Antibak- teri Isolat Potensial (Ahamed 2012, Garcia et al. 2012)}

Fermentasi dilakukan dengan menumbuhkan isolat potensial ke dalam $50 \mathrm{~mL}$ media NB, kemudian diinkubasi selama 48 jam pada suhu $28-30^{\circ} \mathrm{C}$ dengan kecepatan $150 \mathrm{rpm}$. Kultur bakteri hasil fermentasi dipindahkan ke dalam tabung sentrifugasi steril dan disentrifugasi dengan kecepatan 3.600 rpm selama 10 menit untuk memisahkan pelet dan supernatan. Supernatan yang telah terpisah dipindahkan ke corong pemisah dan diekstrak menggunakan larutan kloroform $(1: 1 \mathrm{v} / \mathrm{v})$. Ekstrak kloroform dikenakan uji aktivitas antibakteri terhadap bakteri uji dengan kloramfenikol sebagai kontrol positif. Selanjutnya, larutan metabolit sekunder yang aktif menghambat bakteri uji dievaporasi pada vakum evaporator dengan suhu $40^{\circ} \mathrm{C}$ hingga terbentuk ekstrak kering.

\section{Identifikasi Senyawa Antibakteri dengan Gas Chromatography - Mass Spectrometer (GC- MS)}

Senyawa metabolit sekunder yang aktif dari hasil ekstraksi dilarutkan dengan aseton, kemudian diinjeksikan ke alat GC-MS. Proses GC-MS menggunakan kolom kapiler tipe Phase Rtx-5MS dengan panjang $60 \mathrm{~m}$ dan diameter $0.25 \mathrm{~mm}$. Kondisi alat meliputi : suhu kolom $50^{\circ} \mathrm{C}$, gas helium, $S P L$ Temperature $280^{\circ} \mathrm{C}, M S$ Interface $280^{\circ} \mathrm{C}$, pyrolisis temperature $280^{\circ} \mathrm{C}$, dan ion surface $200^{\circ} \mathrm{C}$ (Kusumawati 2014).

\section{HASIL}

\section{Isolat Bakteri Endofit}

Sebanyak 21 isolat murni bakteri endofit telah diperoleh dari hasil isolasi tanaman Tembelekan (Lantana camara L.), yaitu: 13 isolat dari akar (AT), 5 isolat dari batang (BT), dan 3 isolat dari daun (DT). Persentase bakteri endofit yang diisolasi dari Lantana camara disajikan pada Gambar 1.

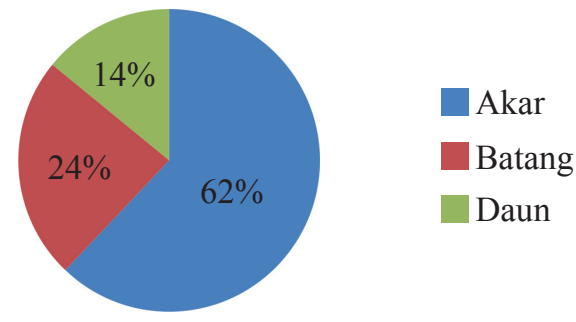

Gambar 1 Persentase isolat bakteri endofit yang diisolasi dari organ tanaman Lantana camara $\mathrm{L}$ 
Tabel 1 Diameter zona hambat yang terbentuk pada seleksi isolat bakteri endofit

\begin{tabular}{cccccc}
\hline \multirow{2}{*}{ No } & Kode & \multicolumn{4}{c}{ Diameter zona hambat (mm) } \\
& Isolat & B. cereus & E. coli & S. aureus & S. enteritidis \\
\hline 1 & AT22 & - & V & - & - \\
2 & AT3 & - & V & - & V \\
3 & BT21 & 2 & 3 & V & - \\
4 & BT22 & 3 & V & 8 & 5 \\
5 & DT11 & - & 1 & 3 & 1 \\
\hline
\end{tabular}

Keterangan $: \mathrm{V}=$ terdapat zona hambat namun sangat kecil dan sulit terukur

\section{Aktivitas Antibakteri dari Isolat Bakteri Endofit terhadap Bakteri Patogen}

Berdasarkan hasil uji aktivitas antibakteri, terdapat 5 isolat yang mampu menghasilkan zona hambat, yaitu AT22, AT3, BT21, BT22 dan DT11 (Tabel 1).

Berdasarkan hasil penelitian, isolat BT22 dianggap paling potensial karena memiliki kemampuan menghambat keempat bakteri patogen yang diujikan. Zona hambat yang terbentuk pada uji aktivitas antibakteri isolat BT22 terhadap Bacillus cereus disajikan pada (Gambar 2).

\section{Analisis Sekuen Gen 16S rRNA dan Kon- struksi Pohon Filogenetik}

Karakterisasi dengan menggunakan analisis gen $16 \mathrm{~S}$ rRNA terhadap isolat yang paling potensial yaitu isolat BT22. Hasil sekuensing isolat BT22 yang telah disejajarkan menunjukkan bahwa gen 16S rRNA pada isolat tersebut berukuran $1477 \mathrm{pb}$ (pasang basa). Hasil analisis gen 16S rRNA menunjukkan bahwa isolat BT22 memiliki kemiripan sebesar 99\% terhadap $\mathrm{Ba}$ cillus amyloliquefaciens.

Analisis dengan pohon filogenetik digunakan untuk mengetahui kedekatan isolat BT22 terhadap Bacillus amyloliquefaciens dan juga untuk mengetahui hubungan kekerabatan dengan jenis spesies lain. Pohon filogenetik menunjukkan bahwa isolat BT22 memiliki hubungan kekerabatan yang paling dekat dengan Bacillus amyloliquefaciens (Gambar 3).

\section{Aktivitas Antibakteri Ekstrak Kloroform Isolat BT22}

Berdasarkan hasil uji aktivitas antibakteri ekstrak kloroform terlihat bahwa ekstrak kloroform BT22 membentuk zona hambat di sekitar sumur. Diameter zona hambat yang terbentuk dari uji aktivitas antibakteri ekstrak kloroform isolat potensial BT22 terhadap bakteri patogen yaitu Bacillus cereus, Escherichia coli, Staphylococcus aureus, dan Salmonella enteritidis masing-masing sebesar $3 \mathrm{~mm}, 7 \mathrm{~mm}, 2 \mathrm{~mm}$, dan 1 $\mathrm{mm}$. Kemampuan isolat potensial menghambat Bacillus cereus ditunjukkan pada Gambar 4.

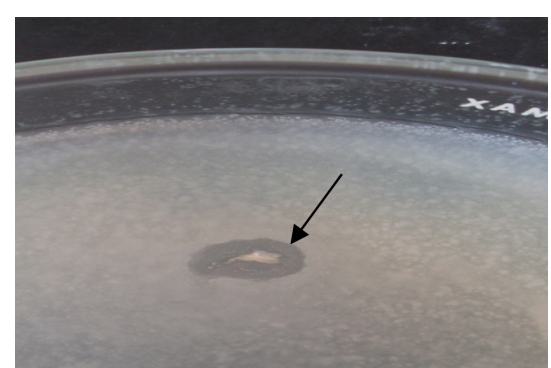

Gambar 2 Zona hambat yang terbentuk pada uji aktivitas antibakteri isolat BT22 terhadap Bacillus cereus (tanda panah) 


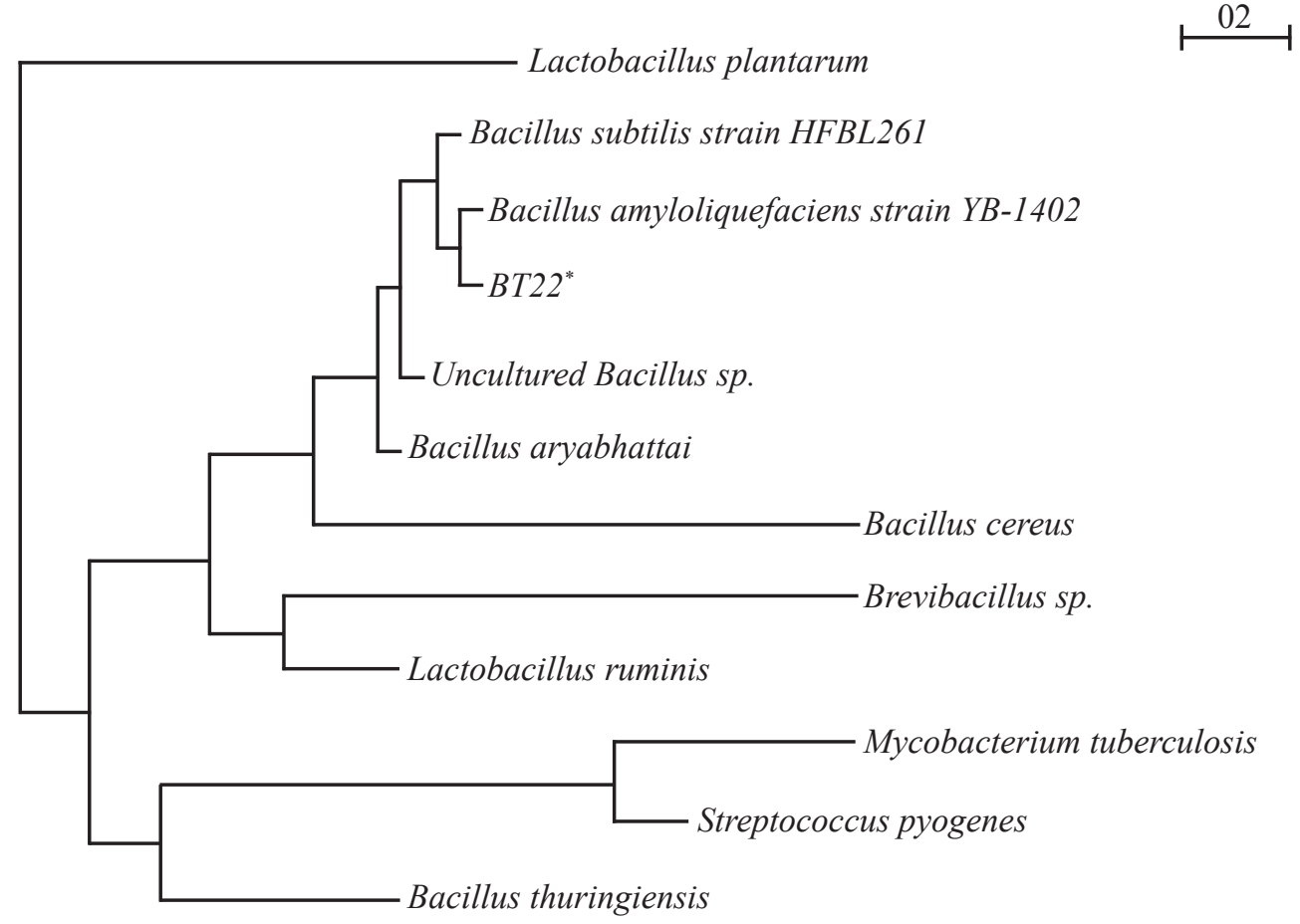

Keterangan : * = isolat BT22 yang diisolasi dari tanaman Lantana camara $\mathrm{L}$.

Gambar 3 Pohon Filogenetik Isolat BT22 dengan metode NJPlot

\section{Senyawa Antibakteri Ekstrak Kloroform Isolat BT22 dengan Analisis GC-MS}

Identifikasi komponen senyawa dalam ekstrak kloroform isolat BT22 dengan menggunakan analisis GC-MS. Selanjutnya identifikasi golongan senyawa antibakteri diperoleh dengan mencocokkan struktur molekul senyawa serta rumus molekul hasil analisis GC-MS dengan hasil analisis pustaka. Senyawa dengan konsentrasi tertinggi adalah Cyclohexanone, 2-[2-(1,3-dithiolan-2-yl)propyl]-6-methyl-3-(1-methylethyl) dengan konsentrasi 42.74\%, Octadecane (CAS) n-Octadecane dengan konsentrasi $14.42 \%$ dan Tetracosane (CAS) n-Tetracosane dengan konsentrasi 10.39\% (Gambar 5).
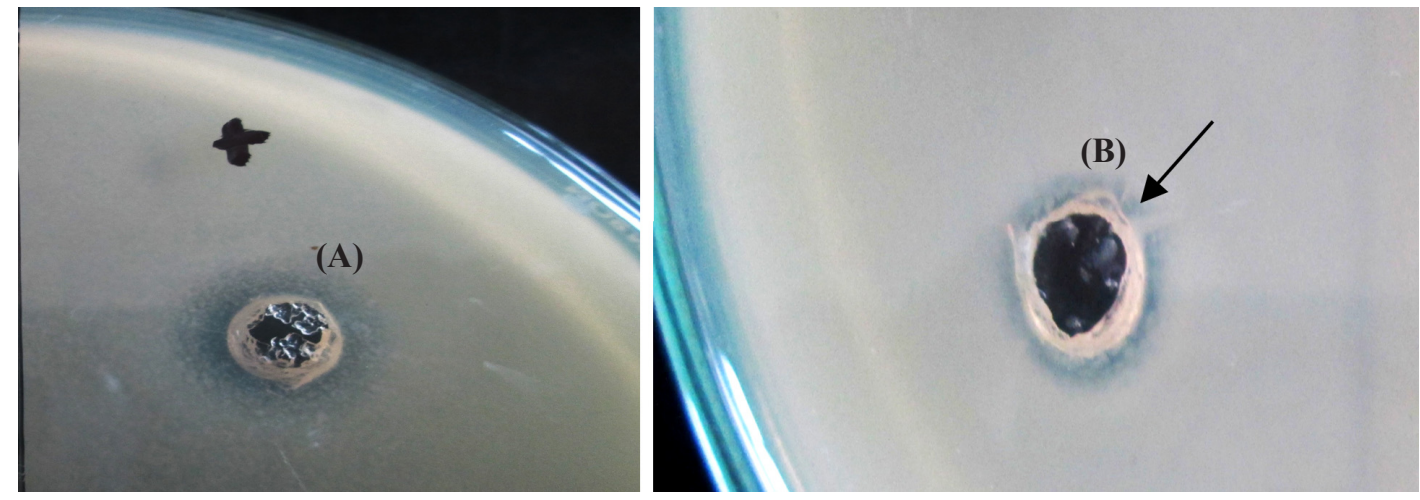

Gambar 4 Zona hambat hasil uji antibakteri ekstrak kloroform isolat BT22 terhadap Bacillus cereus. (A) kontrol positif kloramfenikol $60 \mu \mathrm{g} / \mathrm{mL}$, (B) ekstrak kloroform isolat BT22 (tanda panah) 


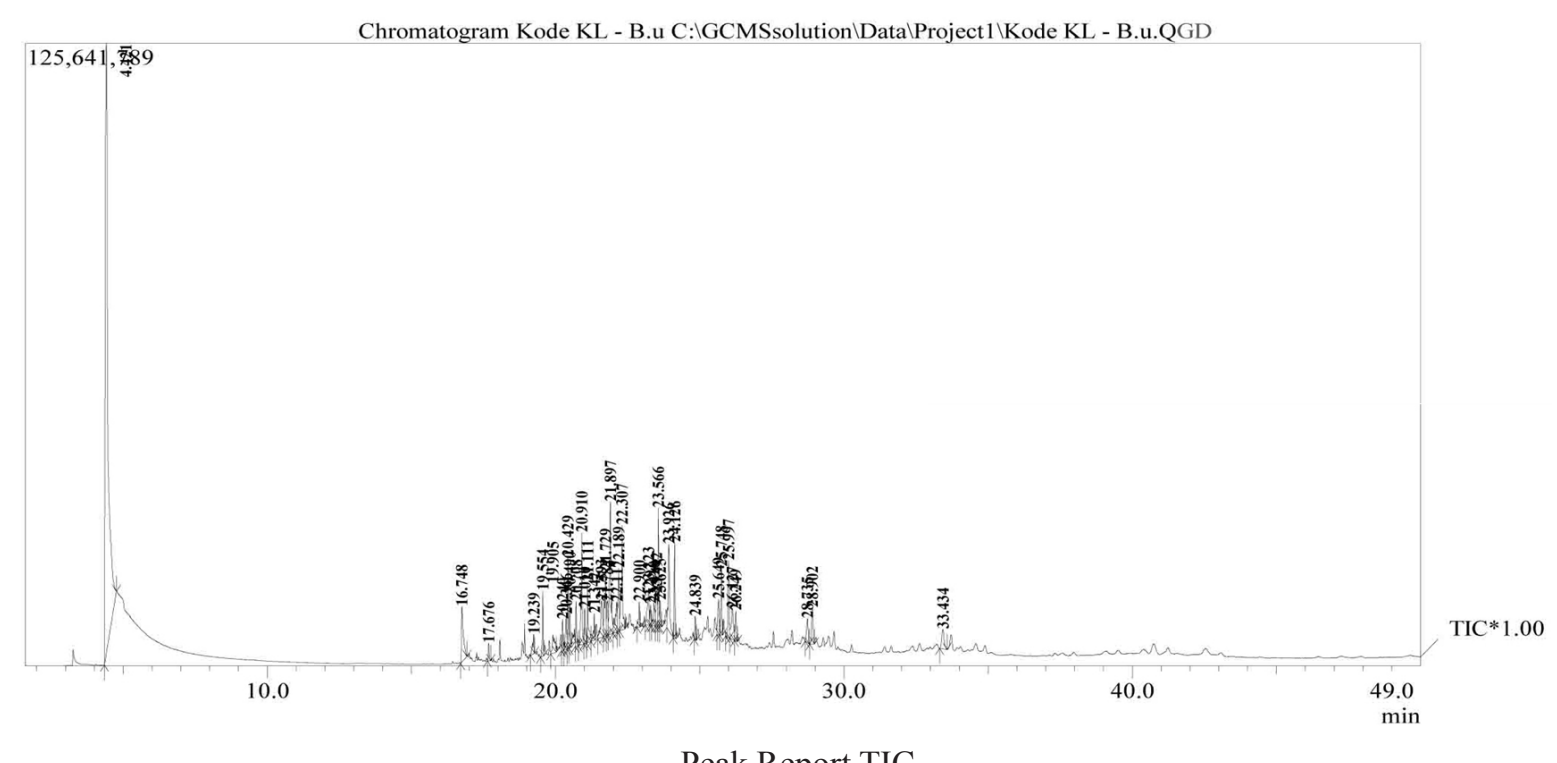

Gambar 5 Kromatogram hasil analisis GC-MS ekstrak kloroform isolat BT22

\section{PEMBAHASAN}

\section{Isolat Bakteri Endofit}

Hasil isolasi bakteri endofit dari tanaman Lantana camara L. didapatkan sebanyak 21 isolat di antaranya 13 isolat dari akar (AT), 5 isolat dari batang (BT), dan 3 isolat dari daun (DT) (Gambar 1). Bakteri endofit dapat diisolasi dari bagian akar, daun, batang, bunga, buah, dan biji (Lodewyckx 2002). Jumlah bakteri endofit yang dihasilkan banyak terdapat di bagian akar. Secara umum, bakteri endofit banyak terdapat di akar dan semakin menurun jumlahnya pada batang dan daun (Lamb et al. 1996). Hal ini disebabkan karena bakteri endofit masuk ke jaringan tanaman pertama kali melalui akar. Bakteri masuk ke jaringan tumbuhan melalui akar kecambah, stomata, atau melalui kerusakan bagian tanaman (Zinniel et al. 2002). Perakaran tanaman (rhizosfer) banyak mengandung asam amino dan gula yang digunakan sebagai sumber nutrisi bagi bakteri endofit (Sylvia 2005), sehingga jaringan internal bagian perakaran memiliki kerapatan populasi bakteri paling tinggi dibandingkan bagian tanaman lain (Hallman 1997).

\section{Aktivitas Antibakteri dari Isolat Bakteri Endofit terhadap Bakteri Patogen}

Uji aktivitas antibakteri dari isolat bakteri endofit dilakukan dengan metode inokulasi titik terhadap bakteri uji. Berdasarkan hasil uji aktivitas antibakteri yang ditunjukkan pada Tabel 1, isolat AT22, AT3, BT21, BT22, dan DT11 mampu menghasilkan zona hambat. Isolat mikroba endofit dikatakan mempunyai aktivitas antimikroba jika terbentuk zona jernih di sekeliling isolat mikroba endofit yang ditumbuhkan pada media yang telah diinokulasi oleh mikroba patogen (Simarmata et al. 2007). Hal ini menandakan bahwa isolat tersebut berpotensi sebagai antibakteri. Perbedaan diameter zona hambat kemungkinan disebabkan oleh kandungan senyawa antibakteri yang berbeda (Kusumawati 2014) dan diameter dinding sel bakteri patogen (Junanto et al. 2008). Berdasarkan hasil penelitian, isolat BT22 dianggap paling potensial kare- 
na memiliki kemampuan menghambat keempat bakteri uji.

\section{Analisis Sekuen Gen 16S rRNA dan Rekons- truksi Pohon Filogenetik}

Urutan sekuen basa gen 16S rRNA dibandingkan dengan urutan basa yang telah tersimpan dalam NCBI-GenBank database. Hasil sekuensing isolat BT22 yang telah disejajarkan menunjukkan bahwa gen 16S rRNA pada isolat tersebut berukuran $1477 \mathrm{pb}$ (pasang basa). Berdasarkan hasil analisis sekuen 16S rRNA menggunakan program BLAST, isolat BT22 memiliki persentase kemiripan dengan Bacillus amyloliquefaciens strain YB-1402 sebesar 99\%. Hal ini didukung dengan rekonstruksi pohon filogenetik untuk mengetahui hubungan kekerabatan antar spesies bakteri. Pensejajaran sekuen hasil penelitian dan beberapa sekuen bakteri lain yang diambil dari NCBI-GenBank database dengan menggunakan clustalX2. Kemudian hasil pensejajaran dimasukkan ke dalam NJPlot untuk merekonstruksi pohon filogenetik (Singh et al. 2011). Hasil rekonstruksi pohon filogenetik menunjukkan bahwa isolat BT22 memiliki hubungan kekerabatan yang paling dekat dengan Bacillus amyloliquefaciens (Gambar 3).

Bacillus merupakan genus bakteri Gram positif yang memiliki ciri morfologi berbentuk batang dan banyak terdapat di dalam tanah (Niazi 2014). Bacillus amyloliquefaciens termasuk bakteri Gram positif yang dapat menghasilkan senyawa metabolit sekunder dan berperan sebagai antimikroba. Jenis senyawa antimikroba yang mampu disintesis di antaranya senyawa antibakteri berupa poliketida (basilaen, diffisidin, dan makrolaktin), senyawa antifungi berupa lipopeptida (surfaktin, fengysin, dan basilomisin D) (He et al. 2013), siderophora (basilibaktin)
(Scholz et al. 2011), dan antibiotik iturin A (Lin et al. 2007). Senyawa antimikroba tersebut dihasilkan melalui sintesis nonribosomal peptida dengan bantuan enzim nonribosomal peptide-synthetase (NRPS) yang terdapat di dalam operon Bacillus amyloliquefaciens (He et al. 2013).

Bacillus amyloliquefaciens memiliki kemampuan untuk mempercepat pertumbuhan tanaman dan menekan pertumbuhan fungi serta bakteri fitopatogenik (Qiao et al. 2014). Senyawa metabolit sekunder yang dihasilkan oleh Bacillus amyloliquefaciens mampu menghambat pertumbuhan Methicilin-resistant Staphylococcus aureus (MRSA) (Nasrin et al. 2015). Bacillus amyloliquefaciens mampu mensintesis makromolekul protein dari alam yang dapat menginduksi daya resistensi tanaman tomat (Solanum lycopersicum) terhadap bercak bakteri yang disebabkan oleh Xanthomonas vesicatoria (Filho et al. 2013).

\section{Aktivitas Antibakteri Ekstrak Kloroform Isolat BT22}

Fermentasi dilakukan untuk mengisolasi senyawa metabolit sekunder pada isolat BT22. Pemilihan supernatan pada hasil sentrifugasi dikarenakan senyawa antibakteri yang dihasilkan oleh isolat BT22 bersifat ekstraseluler. Metabolit sekunder dihasilkan secara ekstraseluler sehingga dilakukan pemisahan sel bakteri dalam supernatan untuk mengekstrak metabolit sekunder (Seo et al. 2010). Supernatan diperoleh melalui proses sentrifugasi untuk mengendapkan sel bakteri, sehingga supernatan hanya mengandung hasil metabolisme bakteri (Savadogo et al. 2004).

Ekstraksi dilakukan dengan menggunakan pelarut kloroform dikarenakan sifatnya yang 
non-polar sehingga dapat melarutkan senyawasenyawa organik, diantaranya senyawa golongan lipid. Selanjutnya ekstrak kloroform isolat BT22 diujikan kembali dengan bakteri patogen Bacillus cereus, Escherichia coli, Staphylococcus aureus, dan Salmonella enteritidis. Kloramfenikol digunakan sebagai kontrol positif karena merupakan antibiotik bakteriostatik berspektrum luas yang aktif terhadap organisme-organisme aerobik dan anaerobik bakteri Gram positif maupun negatif (Katzung \& Lofholn 2004). Berdasarkan hasil uji terlihat bahwa ekstrak kloroform isolat BT22 memiliki aktivitas antibakteri dengan terbentuknya zona bening di sekitar lubang sumur (Gambar 4).

\section{Senyawa Antibakteri Ekstrak Kloroform Isolat BT22 dengan Analisis GC-MS}

Senyawa-senyawa yang teridentifikasi pada analisis GC-MS tidak semuanya termasuk dalam senyawa golongan antibakteri. Hasil analisis GC-MS ekstrak kloroform isolat BT22 (Gambar 5) menunjukkan beberapa senyawa yang berpotensi sebagai senyawa antibakteri. Senyawa dengan konsentrasi tertinggi adalah $C y$ clohexanone, 2-[2-(1,3-dithiolan-2-yl)propyl]6-methyl-3-(1-methylethyl) menunjukkan peak tertinggi dengan konsentrasi $42.74 \%$ pada waktu retensi 4.421. Jha et al. (2013) melaporkan bahwa reaksi asam aminobenzoat / aminopiridin dengan keton (asetil aseton / sikloheksanon) dan benzaldehid menghasilkan senyawa asam benzoat / piridin yang menunjukkan aktivitas antibakteri dan antifungi.

Senyawa dengan konsentrasi tertinggi kedua adalah Octadecane (CAS) n-Octadecane dengan konsentrasi $14.42 \%$. Octadecane merupakan senyawa golongan alkana yang memiliki efek antimikroba, terutama terhadap $S$. aureus dan E. coli (Shkiri et al. 2014). Senyawa dengan konsentrasi tertinggi ketiga adalah Tetracosane (CAS) n-Tetracosane dengan konsentrasi $10.39 \%$. Tetracosane merupakan senyawa hidrokarbon alifatik (Kalegari et al. 2011) golongan alkana (Sonibare et al. 2007). Senyawa ini belum ada laporan ilmiah terkait perannya sebagai antibakteri, namun penelitian sebelumnya telah melaporkan bahwa senyawa Tetracosane memiliki aktivitas sitotoksik terhadap sel kanker usus besar HT-29 dengan menginduksi apoptosis (Uddin et al. 2012). Hal ini menandakan bahwa meskipun belum diketahui perannya sebagai antibakteri, namun Tetracosane telah diketahui berperan dalam bidang medis. Docosane (CAS) n-Docosane sebanyak 6.77\% pada hasil analisis GC-MS. Ekstrak T. alexandri dengan salah satu komponen senyawa utamanya Docosane bersifat antibakteri terhadap bakteri Gram-positif maupun Gram-negatif (Uma \& Parvathavarthini).

Eicosane (CAS) n-Eicosane merupakan senyawa yang muncul dengan konsentrasi $3.58 \%$. Senyawa Eicosane dari ekstrak tanaman Ceratonia siliqua menunjukkan aktivitas antibakteri, antifungi, serta efek sitotoksik terhadap sel kanker HeLa dan MCF-7 (Hsouna et al. 2011). Tetratetracontane (CAS) n-Tetratetracontane sebanyak $1.60 \%$ merupakan senyawa golongan alkana (Kanimozhi \& Bai 2012). Senyawa ini diketahui sebagai komponen dari daun dan biji Syzygium cumini, tanaman obat yang digunakan sebagai antibakteri dan antiinflamasi (Kumar et al. 2011). Nonacosane (CAS) n-Nonacosane terdeteksi dengan konsentrasi $1.69 \%$ adalah senyawa golongan alkana (Kanimozhi \& Bai 2012). Senyawa ini terdapat pada akar B. lancifolium dan memiliki aktivitas antibakteri terhadap Staphylococcus aureus ATCC 
6538, Staphylococcus aureus ATCC 29213, E. coli ATCC 25923, E. coli ATCC 29988, Proteus mirabilis ATCC 43071 (Saracoglu et al. 2012). Benzene, 1,2-dimethoxy-4-(2-propenyl)- (CAS) Methyleugenol sebanyak 2.63\%, biasa dikenal dengan nama Methyl Eugenol (ME). ME merupakan senyawa phenylpropanoid, turunan dari phenylalanin yang banyak terkandung dalam tanaman obat (Tan \& Nishida 2012). Pertumbuhan Campylobacter jejuni, bakteri penyebab penyakit gastroenteritis pada manusia dapat dihambat oleh tanaman wortel dengan kandungan minyak esensial berupa ME dan elemisin (Rossi et al. 2007). Phenol, 2,4-bis(1,1-dimethylethyl)(CAS) 2,4-Di-tert-buthylphenol sebanyak 0.37\% merupakan senyawa aromatik yang terdiri dari fenol, asam karboksilat aromatik, dan ester (Roy et al. 2010). Fenol dan asam fenolat merupakan senyawa bioaktif yang berperan sebagai antibakteri pada tanaman obat (Proestos et al. 2005). Fenol dan asam karboksilat memiliki aktivitas antimikroba pada Sesame radiatum (Shittu et al. 2007). 1,2-Benzenedicarboxylic acid, dibutyl ester (CAS) Buthyl phthalate sebanyak 2.92\% merupakan senyawa golongan triterpenoid berstruktur siklik, kebanyakan berupa alkohol, aldehid, dan asam karboksilat (Suhada 2013). Senyawa ini biasa dikenal dengan nama Dibuthyl phthalate (DBP). Senyawa ini memiliki aktivitas anti fungi, antibakteri, dan anti malaria (Elija et al. 2012). Triterpenoid mempunyai potensi sebagai antibakteri terhadap E. coli dan S. aureus pada konsentrasi 1000 ppm (Sukadana et al. 2008). Kandungan triterpenoid membuktikan perannya sebagai senyawa antibakteri.

Hexadecanoid acid, methyl ester (CAS) Methyl palmitate termasuk senyawa golongan asam palmitat terdeteksi dengan konsentrasi $1.10 \%$. Hexadecanoid acid merupakan kom- ponen utama dari alga merah $F$. hillebrandii yang memiliki potensi sebagai antibiotik karena bersifat antibakteri terhadap Salmonella typhi, Shigella sp., dan Enterococcus faecalis (Manilal et al. 2009). Hexanedioic acid, bis(2-ethylhexyl) ester (CAS) Bis(2-ethylhexyl) adipate dengan konsentrasi sebanyak 1.90\% merupakan senyawa organik yang biasa dikenal dengan asam adipat. Hexanedioic acid yang diisolasi dari larva Hermetia illucens mampu menghambat pertumbuhan bakteri patogen $S$. aureus, $K$. pneumoniae, dan Shigella dysentriae (Chu et al. 2014).

Berdasarkan hasil penelitian, maka dapat disimpulkan bahwa bakteri endofit dapat diisolasi dari tanaman tembelekan (Lantana camara L.). Berdasarkan analisis $16 \mathrm{~S}$ rRNA, isolat BT22 memiliki persentase kemiripan dengan Bacillus amyloliquefaciens strain YB-1402 sebesar 99\%. Hasil GC-MS ekstrak kloroform isolat BT22 menunjukkan terdapat senyawa aktif yang diduga berperan sebagai antibakteri. Senyawa dengan konsentrasi tertinggi adalah Cyclohexanone, 2-[2-(1,3-dithiolan-2-yl)propyl]-6-methyl-3-(1-methylethyl), dan Tetracosane (CAS) nTetracosane, Octadecane (CAS) n-Octadecane.

\section{UCAPAN TERIMAKASIH}

Penulis menyampaikan terima kasih kepada Direktorat Jenderal Pendidikan Tinggi atas Beasiswa Pendidikan Pascasarjana Dalam Negeri (BPPDN) untuk Calon Dosen tahun 2013

\section{DAFTAR PUSTAKA}

Ahamed N. 2012. Isolation and identification of secondary metabolites producing organisms from marine sponge. Discovery. 1 (1) : 14-17. 
Bhore SJ, Satisha G. 2010. Screening of endophytic colonizing bacteria for cytokinin-like compounds: crude cell-free broth of endophytic colonizing bacteria is unsuitable in cucumber cotyledon bioassay. World J. Agric. Sci. 6 (4): 345-352.

Chu KB, Jeon GC, Quan FS. 2014. Hexanedioic acid from Hermetia illucens larvae (Diptera: Stratiomyidae) protects mice against Klebsiella pneumoniae infection. Entomological Research. 44:1-8. DOI: 10.1111/17485967.12043.

Dalimartha S. 2007. Atlas tumbuhan obat Indonesia. Jakarta : Trubus Agriwidya.

Deepak G, Silviya S, Kishwar HK. 2009. Biochemical Compotitions and Antibacterial Activities of Lantana camara Plants with Yellow Lavender, Red and White Flowers. Eurasia. Jour. Bio. Sci. 3:69-77.

Desriani, Kusumawati DE, Rivai A, Hasanah N, Amrinola W, Triatna L, Sukma A. 2013. Potential endophytic bacteria for increasing paddy var rojolele productivity. Int. J. on $A d v$. Sci., Eng. and Information Tech. 3 (1) : 76-78.

Elija K, Vaishali B, Adsul MK, Deshpande NR, Kashalkar RV. 2012. Antibacterial activity of Dibutyl Phthalate : A secondary metabolite isolated from Ipomoea carnea stem. Journal of Pharmacy Research 5(1).

Filho RL, Souza RM, Magalhaes MM, Villela L, Zanotto E, Junior PMR, Resende MLV. 2013. Induced defense responses in tomato against bacterial spot by protein synthesized by endophytic bacteria. Tropical Plant Pathology. 38(4): 295-302.

Garcia A, Rhoden SA, Bernardi WJ, Orlandelli RC, Azevedo JL, Pamphile JA. 2012. Antimicrobial activity of crude extracts of endophytic fungi isolated from medicinal plant Sapindus saponaria L. journal of Applied Pharmaceutical Science. 2 (10) : 35-40.

Hallman J, Quadt-Hallman A, Mahafee WF, Kloepper JW. 1997. Bacterial endophytic in agricultural crops. Can. J. Microbiol. 43 : 895914.
He P, Hao K, Blom J, Ruckert C, Vater J, Mao Z, Wu Y, Hou M, He P, He Y, Borriss R. 2013. Genome sequence of the plant growth promoting strain Bacillus amyloliquefaciens subsp. Plantarum B9601-Y2 and expression of mersacidin and other secondary metabolites. J. biotechnol. Page: 1-11. DOI: 10.1016/ j.jbiotec.2012.12.014.

Hsouna AB, Trigui M, Mansour RB, Jarraya RM, Damak M, Jaoua S. 2011. Chemical composition, cytotoxicity effect and antimicrobial activity of Ceratonia siliqua essential oil with preservative effects against Listeria inoculated in minced beef meat. International Journal of Food Microbiology. 148: 66-72. DOI: 10.1016/j.ijfoodmicro.2011.04.028.

Jha A, Yashmeen S, Kumar DN. 2013. An innovative green synthesis of some Schiff bases and their antimicrobial activity. Int J Pharm Bio Sci. 4(4) : 197-204.

Junanto T, Sutarno, Supriyadi. 2008. Aktivitas antimikroba estrak Angsana (Pterocarpus indicus) terhadap Bacillus subtilis dan Klebsiella pneumoniae. Bioteknologi 5(2): 63-69.

Kalegari M, Miguel MD, Dias JDFG, Lordello ALL, Lima CPD, Miyazaki CMS, Zanin SMW, Verdam MCDS, Miguel OG. 2011. Phytochemical constituents and preliminary toxicity evaluation of leaves from Rourea induta Planch. (Connaraceae). Brazilian Journal of Pharmaceutical Sciences. 47(3): 635-642.

Kanimozhi D, Bai VR. 2012. Analysis of bioactive components of ethanolic extract of Coriandrum sativum L. International Journal of Research in Pharmacy and Science. 2(3): 97-110.

Katzung BG, Lofholn PW. 2004. Penentuan Penggunaan Obat dan Penggunaan Resep Secara Rasional dalam Farmakologi Dasar dan Klinik. Buku 3. Edisi Kedelapan. Jakarta: Penerbit Salemba Medika. p 609.

Kumar V, Bhatnagar AK, Srivastava JN. 2011. Antibacterial activity of crude extracts of Spirulina platensis and its structural elucidation of bioactive compound. J. Med. Plants Res. 5(32): 7043-7048. DOI: 10.5897/ JMPR11.1175. 
Kusumawati, DE. 2014. Isolasi dan Karakterisasi Senyawa Antibakteri dari Bakteri Endofit Tanaman Miana (Coleus scutellariodes [L.] Benth.) [Tesis]. Bogor : Institut Pertanian Bogor.

Lamb TG, Tonkyn DW, Kluepfel DA. 1996. Movement of Pseudomonas aureofaciens from the rhizosphere to aerial plant tissue. Can. J. Microbiol. 42:1112-1120.

Lin HY, Rao YK, Tzeng YM. 2007. Ferrous ion enhanced lipopeptide antibiotic Iturin A production from Bacillus amyloliquefaciens B128. Int. J. Appl. Sci. Eng. 5(2): 123-132.

Lodewyckx C, Vangronsveld J, Porteous F, Moore ERB, Taghavi S, Mezgeay M, Van DLD. 2002. Endophytic bacteria and their potential applications. Crit Rev Plant Sci 21: 583606.

Manilal A, Sujith S, Selvin J, Shakir C, Kiran GS. 2009. Antibacterial activity of Falkenbergia hillebrandii (Born) from the Indian coast against human pathogens. International Journal of Experimental Botany. 78:161166.

Mary KV. 2011. Studies on phytochemical screening and antibacterial activities of Lantana camara. Plant. Sci. Feed. 1: 74-79.

Nasrin S, Hossain MJ, Liles MR. 2015. Draft genome sequence of Bacillus amyloliquefaciens AP183 with antibacterial activity against Methicillin-Resistant Staphylococcus aureus. JournalsASM.org 3(2): 1-2.

Niazi A. 2014. Genome-wide analyses of Bacillus amyloliquefaciens strain provide insights into their beneficial role on plants [Disertasi]. Uppsala: Swedish University of Agricultural Sciences.

Proestos C, Chorianopoulos N, Nychas GJ, Komaitis M. 2005. RPHPLC analysis of the phenolic compounds of plant extracts. Investigation of their antioxidant capacity and antimicrobial activity. J Agric Food Chem. 53:1190-1195.

Purwanto UMS. 2013. Penapisan dan identifikasi bakteri endofit dari tanaman binahong dan ketepeng cina penghasil senyawa antibakteri patogen. Skripsi, IPB.
Qiao JQ, Wu HJ, Huo R, Gao XW, Borriss R. 2014. Stimulation of plant growth and biocontrol by Bacillus amyloliquefaciens subsp. Plantarum FZB42 engineered for improved action. Chemical and Biological Technologies in Agriculture. 1(12): 1-14.

Rossi PG, Bao L, Luciani A, Panighi J, Desjobert JM, Costa J, Casanova J, Bolla JM, Berti L. 2007. (E)-Methylisoeugenol and Elemicin: Antibacterial Components of Daucus carota L. Essential Oil against Campylobacter jejuni. J. Agri. Food Chem. 55(18): 7332-7336. DOI: $10.1021 / \mathrm{jf070674u.}$

Roy S, Rao K, Bhuvaneswari CH, Giri A, Mangamoori LN. 2010. Phytochemical analysis of Andrographis paniculata extract and its antimicrobial activity. World J Microbiol Biotechnol. 26: 85-91. DOI: 10.1007/ s11274-009-0146-8.

Saracoglu HT, Akin M, Demirci B, Baser KHC. 2012. Chemical composition and antibacterial activity of essential oils from different parts of some Bupleurum L. species. Afr. J. Microbiol. Res. 6(12): 2899-2908. DOI: 10.5897/AJMR11.1097.

Savadogo A, Cheik ATO, Imael HNB, Alfred ST. 2004. Antimicrobial Activities of Lactic Acid Bacteria Strains Isolated from Burkina Faso Fermented Milk. Pakistan Journal of Nutrition. 3 (3): 174-179.

Scholz R, Molohon KJ, Nachtigall J, Vater J, Markley AL, Susmuth RD, Mitchell DA, Borriss R. 2011. Plantazolicin, a novel Microcin B17/Streptolysin S-like natural product from Bacillus amyloliquefaciens FZB42. J. Bacteriol. 193(1): 215-224. DOI: 10.1128/ JB.00784-10.

Seo WT, Lim WJ, Kim EJ, Yun HD, Lee YH, Cho KM. 2010. Endophytic bacterial diversity in the Young Radish and their antimicrobial activity against pathogens. J. Korean Soc. Appl. Biol. Chem. 53(4): 493-503.

Shkiri FH, Soussi LSR, Zakhama AEA, Mahjoub A, Flamini G, Jannet HB. 2014. Chemical composition and antibacterial activity of essential oils from the tunisian Allium nigrum L. EXCLI Journal. 13: 526-535. 
Shittu LAJ, Bankole MA, Ahmed T, Bankole MN, Shittu RK, Saalu CL, Ashiru OA. 2007. Antibacterial and antifungal activities of essential oils of crude extracts of Sesame radiatum against some common pathogenic microorganisms. Iran J Pharmacol Ther 6:165-170.

Sylvia D, Fuhrmann J, Hartel P, Zuberer D. 2005. Principles and Application of Soil Microbiology. Pearson Education Inc. New Jersey.

Simarmata R, Lekatompessy S, Sukiman H. 2007. Isolasi mikroba endofit dari tanaman obat sambung nyawa (Gymura procumbens) dan analisis potensinya sebagai antimikroba. Berk Penel Hayati 13 : 85-90.

Singh V, Chaudhary DK, Mani I. 2011. Molecular characterization and modeling of secondary structure of 16s rrna from Aeromonas veronii. International Journal of Applied Biology and Pharmaceutical Technology. 3 (1): 253260.

Sonibare MA, Soladoye MO, Ogunlana YE. 2007. A chemotaxonomic approach to the alkane content of three species of Anthocleista Afzel. (Loganiaceae). Afr. J. Biotechnol. 6(13): 1516-1520.

Suhada A. 2013. Identifikasi senyawa dalam ekstrak batang Songga (Strychnos ligustrina) dengan metode GC-MS [Tesis]. Yogyakarta: Universitas Gadjah Mada.

Sukadana IM, Santi SR, Juliarti NK. 2008. Aktivitas antibakteri senyawa golongan triterpenoid dari biji Pepaya (Carica papaya L.). Jurnal Kimia. 2(1): 15-18.

Tan KH, Nishida R. 2012. Methyl eugenol: Its occurrence, distribution, and role in nature, especially in relation to insect behavior and pollination. Journal of Insect Science. 12(56): $1-74$.

Uddin SJ, Grice D, Tiralongo E. 2012. Evaluation of cytotoxic actvity of patriscabratine, tetracosane, and various flavonoids isolated from the Bangladeshi medicinal plant Acrotichum auruem. Pharmaceutical Biology. 50(10): 1276-1280. DOI: 10.3109/13880209.2012. 673628 .
Uma B, Parvathavarthini R. 2010. Antibacterial effect of hexane extract of sea Urchin, Temnopleurus alexandri (Bell,1884). Int. J. PharmTech Res. 2(3): 1677-1680.

Zinniel DK, Lambrecht P, Harris BN, Feng Z, Kuczmarski D, Higley P, Ishimaru CA, Arunakumari A, Barletta RG, Vidaver AK. 2002. Isolation and characterization of endophytic colonizing bacteria from agronomic crops and prairie plants. Applied and Environmental Microbiology. 68(5): 2198-2208. 